\title{
Influx of Bis 2 Amino Pyridinium Maleate with Ethanol
}

\author{
K SenthilKannan* \\ Dean R\&D, Vice Principal \& Research Scientist, Edayathangudy G.S Pillay Arts and Science College, \\ Nagapattinam 611002 TN India \\ *Corresponding Author: K SenthilKannan, Dean R\&D, Vice Principal \& Research Scientist, \\ Edayathangudy G.S Pillay Arts and Science College, Nagapattinam 611002 TN India
}

\begin{abstract}
Abs tract: Bis 2 Amino Pyridinium Maleate (B2APM) crystals are NLO in nature and are grown by solution growth method, since NLO materials are widely used for number of variety of applications such as ease of fabricating, high stability and wide range of transparency of light; they are proposed to be grown as the titled specimen. The single XRD data confirms that this crystal is having a as $21.760 \AA$, $b$ as $23.555 \AA$, c as $5.626 \AA$, $\alpha=\beta=\gamma=90$ o and the crystal is orthorhombic in nature, Fdd2 is the space group of Bis 2 Amino Pyridinium Maleate crystals. Structure is the combination of $2 \mathrm{C} 5 \mathrm{H} 7 \mathrm{~N} 2+. \mathrm{C} 4 \mathrm{H} 2 \mathrm{O} 4$-.
\end{abstract}

Keywords: $B 2 A P M, X R D, N L O \ldots$

\section{EXPERIMENTAL}

The B2APM was prepared by suspend 2-aminopyridine and maleic acid in 2:1 molar ratio in water at $100 \mathrm{oC}$. Crystals of B2APM were acquired by slow evaporation of the solvent at the room temperature.

The reaction mechanism is

$$
2 \mathrm{C}_{5} \mathrm{H}_{6} \mathrm{~N}_{2}+\mathrm{C}_{4} \mathrm{H}_{4} \mathrm{O}_{4} \rightarrow 2 \mathrm{C}_{5} \mathrm{H}_{7} \mathrm{~N}_{2}{ }^{+} \cdot \mathrm{C}_{4} \mathrm{H}_{2} \mathrm{O}_{4}{ }^{2-}
$$

\section{INFLUX}

Influx is measured by water in B2APM crystals and is found to be 2.5872 microns

\section{CONCLUS ION}

B2APM crystals are grown by slow evaporation method and here the grown material is subjected to $\mathrm{XRD}, \mathrm{NLO}$ and FL and from that it is orthorhombic in nature. The single XRD data confirms that this crystal is having a as $21.760 \AA, b$ as $23.555 \AA$, c as $5.626 \AA, \alpha=\beta=\gamma=90$ o. The influx is 2.5872 microns

\section{REFERENCES}

[1] Buckley. H.E, Crystal Growth', Chapman and Hall, London (1952)

[2] Elmer. T.H, Am.Ceram.Soc.Bull.32,23, (1953)

[3] Cabrera. N, Levine. M. M,Phil. Mag. 1,450, (1956)

[4] Campbell. J.E, High Temperature Technology, Wiley, New York, (1959)

[5] Adamski.J.A,J.Appl.phys,36,1784,(1965)

[6] Bennema. P, Ph.D Thesis, Tech. Univ. Delft, Groningen, Netherlands (1965)

[7] Bravais. A,Etudes Cristallographique, Paris, Cauthier Villars, (1966)

[8] Bennema. P, Kern.R and simon. B, Phys.Stat.Sol.19,211,(1967)

[9] Adamski. J.A, powell. R.C and Sampson. R.L, ICCG Brmingham, 246,(1968)

[10] Cockayne. B and Gasson. D.B,J. Materials Sci. 5,837,(1970)

[11] Eickhoff. K and Gurs. K. J. Crystal Growth, 6,21,(1970)

[12] Ankrum. P.D, Semicondutor Electronics, prentice-Hall, Jersey, (1971) 
[13] Domey. K.F, Solid State Tech.41 (1971)

[14] Bardsley. W, Green. G.W, and Hurle. D.T.J,J. Crystal Growth, 16,277, (1972)

[15] Bardsley. W, Hurle. D.T.J, and Joyce. C.G, J. Crystal Growth,40, 33,(1974)

[16] Spek, A. L. (2009). Acta Cryst. D65, 148-155

Citation: K. SenthilKannan, "Influx ofBis 2 Amino Pyridinium Maleate with Ethanol", International Journal of Advanced Research in Chemical Science (IJARCS), vol. 5, no. 2, pp. 8-9, 2018. http://dx.doi.org/10.20431/ 2349-0403.0505002

Copyright: () 2018 Authors. This is an open-access article distributed under the terms of the Creative Commons Attribution License, which permits unrestricted use, distribution, and reproduction in any medium, provided the original author and source are credited. 